\title{
Sestina! or, The Fate of the Idea of Form
}

\section{Citation}

Burt, Stephen. 2007. Sestina! or, the fate of the idea of form. Modern Philology 105, no. 1: 218-241.

\section{Published Version}

http://dx.doi.org/10.1086/587209

\section{Permanent link}

http://nrs.harvard.edu/urn-3:HUL.InstRepos:3426325

\section{Terms of Use}

This article was downloaded from Harvard University's DASH repository, and is made available under the terms and conditions applicable to Other Posted Material, as set forth at http:// nrs.harvard.edu/urn-3:HUL.InstRepos:dash.current.terms-of-use\#LAA

\section{Share Your Story}

The Harvard community has made this article openly available.

Please share how this access benefits you. Submit a story.

Accessibility 


\title{
Sestina! or, The Fate of the Idea of Form
}

\author{
STEPHEN BURT \\ Harvard University
}

There seem to be a lot of sestinas lately. James Cummins and David Lehman have just published a book of them; the online version of the journal McSweeney's ran, until 2007, a poetry section that published nothing else. ${ }^{1}$ At least one sestina (sometimes three) appears in first or second collections from the past fifteen years by (among others) Brian Blanchfield, Timothy Donnelly, Ben Doyle, Jenny Factor, B. H. Fairchild, Joanna Fuhrman, Noelle Kocot, Randall Mann, Laura Mullen, Geoffrey G. O'Brien, Ethan Paquin, Anna Rabinowitz, Jendi Reiter, Catie Rosemurgy, Prageeta Sharma, Spencer Short, Heidi Lynn Staples, Matthew Thorburn, A. Van Jordan, and Jonah Winter. ${ }^{2}$ Well-known

1. James Cummins and David Lehman, Jim and Dave Defeat the Masked Man (Brooklyn, NY: Soft Skull, 2006); McSweeney's Internet Tendency, Sestinas, 2003-6, http://www. mcsweeneys.net/links/sestinas/.

2. Brian Blanchfield, Not Even Then (Berkeley: University of California Press, 2004), 34-35, 68-69; Timothy Donnelly, Twenty-seven Props for a Production of "Eine Lebenszeit" (New York: Grove, 2003), 50-51; Ben Doyle, Radio, Radio (Baton Rouge: Louisiana State University Press, 2001), 62-63; Jenny Factor, Unraveling at the Name (Port Townsend, WA: Copper Canyon, 2002), 6-7; B. H. Fairchild, Local Knowledge (New York: Norton, 2005), 29-30; Joanna Fuhrman, Ugh Ugh Ocean (Brooklyn, NY: Hanging Loose, 2003), 25-26; Noelle Kocot, 4 (New York: Four Way, 2001), 40-41, 48-49, 61-62; Randall Mann, Complaint in the Garden (Lincoln, NE: Zoo, 2004), 6-7; Laura Mullen, After I Was Dead (Athens: University of Georgia Press, 1999), 76-77; Geoffrey G. O'Brien, Green and Gray (Berkeley: University of California Press, 2007), 73-74; Ethan Paquin, The Violence (Boise, ID: Ahsahta, 2005), 20-21; Anna Rabinowitz, At the Site of Inside Out (Amherst: University of Massachusetts Press, 1998), 14-15, 33-34, 63-64; Jendi Reiter, A Talent for Sadness (Cincinnati: Turning Point, 2003), 54-55; Catie Rosemurgy, My Favorite Apocalypse (St. Paul, MN: Graywolf, 2001), 95-96; Prageeta Sharma, Bliss to Fill (Honolulu: Subpress, 2000), 4; Spencer Short, Tremolo (New York: HarperCollins, 2001), 50-51; Heidi Lynn Staples, Guess Can Gallop (Kalamazoo, MI: New Issues, 2004), 12-14; Matthew Thorburn, Subject to Change (Kalamazoo, MI: New Issues, 2004), 30-31; A. Van Jordan, $M-A-C$ N-O-L-I-A (New York: Norton, 2004), 80-82, 117-18; Jonah Winter, Maine (Raymond, NH: Slope, 2002), 53-58.

(c) 2008 by The University of Chicago. All rights reserved. 0026-8232/2008/10501-0017 $\$ 10.00$ 
periodicals and Web journals have, even more recently, offered sestinas by such poets (all widely published, all with first books out since 1995) as Geoff Bouvier, Joshua Clover, Brian Henry, Ange Mlinko, and Chris Stroffolino. ${ }^{3}$ Few of these poets use much rhyme or regular meter; some never rhyme at all. Their names, as a group, would make poor evidence for anyone who wanted to argue that American poets were now embracing inherited forms in general. Why, then, are they writing so many sestinas?

Introduced into English by Sir Philip Sidney, the sestina got little use until the end of the nineteenth century. David Caplan has described a sestina revival beginning in the 1930s, led (though he does not quite say so) by W. H. Auden; James Breslin called the 1950s-derisively"the age of the sestina." "Edward Brunner, in his important recent study of fifties poetry, writes that during that decade collections "seemed incomplete without a sestina." ${ }^{5}$ Donald Justice, W. S. Merwin, William Meredith, and John Ashbery all published more than one. ${ }^{6}$ Brunner suggests that "in a time of professionalization ... that form which requires a heavy investment in labor is bound to be in ascendance." 7 Yet the more whimsical sestinas of the present, as we will see, seem to question or mock what Brunner dubs "guild skills," even as they demonstrate those skills. If the fifties sestina reflected professionalization, the contemporary sestina perhaps notes dissatisfaction with professionalization, even as it still finds value in craft.

The sestina has served, historically, as a complaint: Does it still? Caplan writes that "the sestina's demands are so harshly arbitrary that they ask to be used metaphorically," as signs for deprivation or duress. ${ }^{8}$ Rather than complain about unrequited love (as in Sidney), material

3. Geoff Bouvier, "Sestina," New American Writing 20 (2002): 100; Joshua Clover, "Das Kissenbuch," McSweeney's Internet Tendency, http://www.mcsweeneys.net/links/sestinas/ 13JoshuaClover.html; Brian Henry, "A Fake Sestina for Hayden Carruth," McSweeney's Internet Tendency, http://www.mcsweeneys.net/links/sestinas/20BrianHenry.html; Ange Mlinko, "A Wrinkle in Time," McSweeney's Internet Tendency, http://www.mcsweeneys.net/ links/sestinas/8AngeMlinko.html; Chris Stroffolino, "In Memory of My Rock Band," Shampoo 24 (2005), http://www.shampoopoetry.com/ShampooTwentyfour/stroffolino.html.

4. Breslin is quoted in David Caplan, Questions of Possibility (New York: Oxford University Press, 2005), 20.

5. Edward Brunner, Cold War Poetry (Urbana: University of Illinois Press, 2001), 161.

6. Donald Justice, New and Selected Poems (New York: Knopf, 1995), 35-40; W. S. Merwin, The First Four Books of Poems (New York: Athenaeum, 1975), 30, 42; William Meredith, Partial Accounts (New York: Knopf, 1987), 25; John Ashbery, The Mooring of Starting Out (Hopewell, NJ: Ecco, 1997), 40, 54.

7. Brunner, Cold War Poetry, 164-65.

8. Caplan, Questions of Possibility, 23. 
poverty or orphanhood (as in Bishop), bad weather or the problem of evil (as in Anthony Hecht), contemporary poets, I will argue, use sestinas to lament their diminished or foreclosed hopes for their art. ${ }^{9}$ The miniboom in sestinas has a contributory cause in the failure of nonformal kinds of poetic ambition, in the nonviability-for writers whose careers began relatively recently-of various programs from the fifties, sixties, and seventies that purported to show poets how to make something happen. Recent sestinas not only reflect but describe that failure. At their best, they meditate on the limits and frustrations of any model of poetry based in technique or in entertainment, and they complain that no other model fits.

Poets who began publishing in the 1990s arrived at the end of a long chain of disappointments: one might even say a line of failed promises. They could look back, if they chose, to academic formalists of the 1950 s, who claimed (following, loosely, T. S. Eliot) that American poetry represented a continuously valid tradition of reconciling existential contradictions and making sense of experience through verbal craft. Rejecting such now frequently stigmatized models, they could look back on the schools of sixties poetry (later anatomized, with varying severity, by Charles Altieri, Paul Breslin, and Alan Williamson), which claimed an organic warrant or a natural connection to a preverbal reality, and on generations of confessional verse-the first led by Robert Lowell, the second avowedly feminist-that promised models through which both poets and readers could escape familial or patriarchal oppression. Many recent poets might find, with Paul Breslin, that these schools, for all their supposed rivalries, reflect "a sentimental greening of the unconscious," with a "common origin in the desire to recover a self disentangled from acculturation and its burden of guilt." 10

Poets who began in the nineties could also look back on claims about social critique and social justice advanced in connection with language writing, which, according to its most ambitious advocates-

9. Philip Sidney, "Ye Gote-herd Gods," in his Poems, ed. William Ringler (Oxford University Press, 1962), 111; Elizabeth Bishop, "A Miracle for Breakfast" and "Sestina," in her Complete Poems, 1927-1979 (New York: Farrar, Straus \& Giroux, 1983), 18, 123; Anthony Hecht, "Sestina d'Inverno," in his Collected Earlier Poems (New York: Knopf, 1990), 135, and "The Book of Yolek," in his The Transparent Man (New York: Knopf, 1990), 73.

10. Paul E. B. Breslin, The Psycho-Political Muse (University of Chicago Press, 1987), 21. 
such as Ron Silliman in The New Sentence-might loosen the shackles of instrumental reason, raise heretofore unavailable questions about "the social dynamics of capitalism," or decommodify culture itself. ${ }^{11}$ "Mainstream" writers throughout the 1980s-Robert Pinsky, for instance-implied that a suitably democratic poetry could represent and reinforce a revival of civil society. In the same years, Jorie Graham's "Self-Portraits," and the autobiographical poems that followed, evidenced what James Longenbach called Graham's "Big Hunger"-her desire for a new understanding of history, meaning, knowledge, and time and her hopes that her poems might construct it. ${ }^{12}$ We can still find such claims in writers of Graham's own generation; Donald Revell's recent prose strikes a positively Emersonian note: "We must not look for poetry in poems," he declares. "Poetry has further to go and greater occasions. As energy it outspeeds the mass and manners of art. . . . It is itself alive, and bursts from poems in actual ecstasy." 13

Yet it is no insult to Revell to note that his claims sound anachronistic, even provocative, and that few of the other contemporary writers named in my first paragraph would make them. Young poets now tend not to believe that the poetry they publish in books and journals can disclose organic preverbal truths, invigorate broad movements for social justice, validate individual writers by linking them to a singular tradition, or strip away social falsities so as to empower or absolve an authentic self. When these ethical, spiritual, political, and historical ambitions fall away, what is left is entertainment and craft or, to put it another way, technique and fun. The sestina is a favored form now as it has not been since the 1950 s, I contend, because it allows poets to emphasize technique and to disavow at once tradition, organicism, and social or spiritual efficacy. The sestinas I will consider here explore, embody, and worry about such disavowals. To see how they work, and how some other contemporary poems that are not themselves sestinas answer them, is to see a problem that a generation of poets seems to find central to the practice of their art now.

\section{I}

Why this form, rather than others? Caplan writes that contemporary poets tend to "use conspicuous rules but deny the rules' authority." 14

11. Ron Silliman, The New Sentence (New York: Roof, 1995), 8.

12. James Longenbach, Modern Poetry after Modernism (New York: Oxford University Press, 1998), 175.

13. Donald Revell, Invisible Green (Richmond, CA: Omnidawn, 2005), 27.

14. Caplan, Questions of Possibility, 25. 
Marjorie Perloff has suggested that contemporary poets in search of formal constraints, but alienated from any particular tradition, turn either to satire of inherited forms (as in Ashbery's poem "The Songs We Know Best") or to arbitrary procedural constraints: the sestina now fits both these purposes. ${ }^{15}$ Unlike the two-part, thesis-anti-thesis structure of the sonnet, for example, or the $a a b$ structure of blues, the six-words seven-times structure of the sestina corresponds to no prominent process in human conversation or in the logic of discursive prose. The less a strict form can be made to look natural, the less it looks like an inevitable consequence of a poem's apparent content, the more it looks like a conscious choice-or a game. Moreover, sestinas, as the form exists today, require neither expertise with inherited meter nor facility with rhyme. Daniel Nester, the sestinas editor for McSweeney's, writes half-jokingly: "The sestina is, to my mind, the one form that poets from all camps can write and appreciate. Formalists love the sestina for its ornate, maddening word repetition; avantgardists love the sestina for its ornate, maddening word repetition." 16

This sense of artificiality, even arbitrary constraint, has fueled the sestina's appeal and suited it to describe poets' sense that their art as a whole corresponds to nothing much. Consider Joanna Fuhrman's "Stable Self Blues": the poet or speaker identifies herself as "just another pizza delivery girl," "a raconteur with nothing / To recount," adding "Mina Loy / Is my favorite video game. / I love blowing up those enemy nouns." ${ }^{17}$ Fuhrman admires Loy but discounts her destructive goals, imagining Loy's modernist project as exciting but self-enclosed and harmless, without immediate ethical consequence. Fuhrman continues, almost flirtatiously: "Nothing / Could really be better than this game // In which nothing feels like it is a game . . Don't think I'm putting down all games." "Stable Self Blues" not only defends a relatively inconsequential (and feminized, even girlish) poetry but furthermore defends inconsequentiality, flimsiness, foolishness, helplessness, and lightness, as such. "The stuffed rabbits on the pillow sleep like the sweetest smallest girl." 18

Furhman's sestina anticipates Sian Ngai's claim that "as a literary genre ... associated with small and compact texts," modern lyric poetry must "negotiate its relationship to cuteness," which is to say childlike-

15. Marjorie Perloff, Radical Artifice (University of Chicago Press, 1991), 138-39.

16. Daniel Nester, "Confessions of a Sestinas Editor," Poets and Writers, January 2005, http://www.pw.org/mag/0501/newsnester.htm.

17. Fuhrman, Ugh Ugh Ocean, 25.

18. Ibid., 26. 
ness, softness, helplessness, portability, purchasability, and femininity: "the commodity aesthetic of cuteness," Ngai continues, can help poetry to consider "the social effeteness of its small and all too easily fetishized texts." ${ }^{19}$ For Fuhrman, contemporary poetry appears doomed to cuteness. It must give pleasure, and it must change; other than that, there is nothing much it must do, even nothing much that it can do, and the sestina-which goes round in circles, displays obvious craft, and mimes a kind of futility-matches those reduced (or realistic) ambitions.

Some poets present those ambitions in harsher tones. Joshua Clover's self-satirizing sestina "Das Kissenbuch" depicts the poet and his poem as impotent latecomers among a cast of dead authors who include Lao Tze, Sun Tzu, Marx, Lucretius, and Hesiod: “The wave of work / Keeps going like a sentence keeps going, gathering material as it goes, and / One lives among this jetsam, is of the jetsam, is quizzical at being a capital / I at this late date." ${ }^{20}$ Clover also imagines "gentlemen of business" reading, without necessarily understanding, Hesiod's Works and Days, which stands to Clover's short poem in the relation of didactic to mock-didactic. Clover's poem is a "work" in the sense that he has made it but not a substantial "work" in the sense of Works and Days, nor does it, in a Marxist's (nor perhaps a physicist's) sense, do work. By mixing his labor with words, the poet has produced nothing useful or special. A similar sense of inutility dominates Matthew Thorburn's sestina "Just You, Just Me," which plays on "justice," on the name Donald Justice, and on the deflating phrase "just us," seeking (but not quite finding) "a new / poem" with "a new / way to remember the old things." 21

Other sestinas describe other sorts of futility. In Jendi Reiter's "Registering Bliss" the difficulties in planning the poet's wedding suggest (and deflate) the difficulties involved in modernist plans to make it new: "Who'd be ready / to smash a whole set of porcelain // just to choose . . . a different pattern of porcelain?" Reiter asks, adding, "Things are made fresh, but never new." ${ }^{22}$ Shanna Compton's "The Remarried Again Sestina" suggests a kind of appalled irritation, both with the sestina form and with the form of life that its bored protagonists enact:

At first, everything was lovely.

He courted her, fresh as a rose.

As a mate he seemed competent.

19. Sian Ngai, "The Cuteness of the Avant-Garde," Critical Inquiry 31 (2005): 815, 838. 20. Clover, "Das Kissenbuch."

21. Thorburn, Subject to Change, 30.

22. Reiter, Talent for Sadness, 54. 
Turns out, he was actually a cock.

But what the hell-she was still young, the house was hers, the kids were good,

and the divorce final. Good

riddance. $^{23}$

"Competent," if never "lovely," the poem challenges its readers to propose some other course of action for "her" life and expresses something near despair about the uses of its own form, in which the same end words, the same life choices, recur without improvement.

Noelle Kocot's first book, 4 (2002), included three sestinas; a fourth appears in the new (and enormous) anthology Legitimate Dangers, whose coeditors advertise it as the successor to Paul Carroll's generation-defining 1968 Morrow Anthology. Kocot's "Gypsy Summer" takes as its end words "moonlight," "floor," "lake" (or "lack"), "addition" (or "ad"), "credit," and "cards": the sestina equates credit in the sense of credence, belief (in Kocot's powers as a poet), the credit on credit cards, and the dubious predictive power of tarot cards. None of the three sources of "credit" pan out:

I spoke in the vocabulary of lack

When I told the Brooklyn gypsy three months later of my spanking credit

And how, if she removed my god-awful curse, I would renounce reading

Tarot cards

For good. ${ }^{24}$

The fortune-teller in the poem charges the speaker $\$ 45,000$ to "prevent all my friends' souls from dispersing in the moonlight." The friends will die anyway, the fortune-teller's promise is a fraud, and only the speaker's mental illness lets her get taken in: "the credit- / Ratings of manic-depressives get so fucked up." ${ }^{25}$ Kocot's overwrought tone creates a parody, in part, of the self-importance common to ambitious poets fresh out of expensive colleges; her fortune-teller becomes a pseudo-vates, a ridiculous version of the poet's once-respected role as seer or prophet, now issuing words whose force no sensible adult should credit. If you believe in poetry, Kocot's sestina implies, you will believe anything.

That sestina not only suggests but, in its claims and tones, describes contemporary poets' frustration over the apparent inefficacy of their art, over their inability to justify the time and the intellectual invest-

23. Shanna Compton, “The Remarried Again Sestina,” McSweeney's Internet Tendency, http://www.mcsweeneys.net/links/sestinas/remarried.html.

24. Noelle Kocot, "Gypsy Summer," in Legitimate Dangers: American Poets of the New Century, ed. Michael Dumanis and Cate Marvin (Louisville, KY: Sarabande, 2006), 226.

25. Ibid. 
ments it requires. We readers may cherish their poetry on no other grounds than that beauty is its own excuse for being, or that any wellmade poem adds to the stock of available reality, but these poets seem only uneasily satisfied-if not outright exasperated-with how little they believe their poems can do.

Other sestina writers make the uselessness of verbal craft a positive ethical reproach, either to poets or to the rest of the world. A. Van Jordan's book M-A-C-N-O-L-I-A (2004) focuses on MacNolia Cox of Akron, Ohio, the first African American finalist in the national spelling bee, prevented from winning when white judges bent the rules. "Almost / the national spelling champ" in the 1930s, Cox returned to Ohio and became "the best damn maid in town." ${ }^{26}$ Her verbal skills did not much improve her life, and her life story calls into question the idea that art, intellect, or verbal skills of any sort can assuage social injustice. The book's first sestina (properly a double sestina) versifies a negative review, in Time magazine, of Josephine Baker's performance in the 1936 Ziegfeld Follies:

This was not the time

For a poor Negro girl to find applause

When she had given up her one true race-

America-for filthy France ...

This is not about her race

But her choice of song, her need for applause. ${ }^{27}$

Baker responds, in part:

I got a man,

He stays with me when I take off the paint,

And he doesn't care about this whole race

Hoopla; he loves Josephine for me. Time

Magazine just started taking the time

To acknowledge Negroes, and now applause

From them is supposed to predict racial

Equality on stage? ${ }^{28}$

Van Jordan's book-here and in the many poems about Coxconcerns displays of conspicuous skill by African Americans, children and adults: Where, how, and how justly are such displays rewarded? Poetry becomes, at least by implication, another such display: Cox's spelling bees and Baker's vocal performances relate to the ancient idea of poetry as making-of poets as colleagues and competitors, of

26. Van Jordan, M-A-C-N-O-L-I-A, 35.

27. A. Van Jordan, "Time Reviews in Ziegfeld Follies Featuring Josephine Baker, 1936," in his $M-A-C-N-O-L-I-A, 80$.

28. Ibid., 81. 
poems as displays of skill-almost as the fortune-teller's flimflam relates, in Kocot, to the idea of poetry as prophecy. For Van Jordan, poems are like dances, and dances are like spelling bees-displays of specialized talent: we want them to do more symbolic and cultural work than we can fairly ask the contestants or performers or poets to pull off. No wonder a performer like Baker (in Van Jordan's poem) refuses the mission: no wonder the reporter who speaks in "Covering the Spelling Bee"-Van Jordan's other sestina-concludes:

In Akron, I'm proud

To say, she [MacNolia] did have a chance, Which, when you think about it, should Be plenty, but it's only enough

When having a fair deal is enough To win. ${ }^{29}$

Verbal skills, technique, and art cannot make the world-or even a spelling bee-fair for Van Jordan; those skills benefit, at best, the artist, and at worst, no one: his sestinas, too, pursue art's failure to find further use.

My hypothesis concerns both particular (and particularly accomplished) recent sestinas and sentiments among younger poets, some of whom responded when I posted that hypothesis on a blog. ${ }^{30}$ Compton wrote that sestinas "are terrific to read aloud because there's a built-in way for the audience to participate/anticipate. Even someone unfamiliar with the form's rules can tell by the end of the second stanza ... what's going on. . . It's fun to hear the audience reacting at the end of each line." ${ }^{31}$ Compton's account of audience influence recalls Robert Lowell's descriptions of how West Coast audiences moved him to reject his early Miltonic style, though for Compton the pressures of performance point in the opposite direction-toward an emphasis on the poem as a technical achievement and away from its resemblance to unpremeditated speech. Chad Parmenter of Southern Illinois University agreed: the sestina, he wrote, has "been revived as a sort of post-form form, that can both show a poet's virtuosity and, through its intense stricture, make fun of form as a whole." ${ }^{2}$ Finally, a respondent calling himself Arnaut Daniel (after

29. A. Van Jordan, "Covering the Spelling Bee," ibid., 118.

30. Stephen Burt, "Trial Run,” post to Accomodatingly blog, December 27, 2005, http://www.accommodatingly.com/?p=293.

31. Personal communication.

32. Chad Parmenter, comment on "Trial Run," post to Accommodatingly blog, December 30, 2006. 
the form's Provençal inventor) calls "many if not most of the sestinas I read by young poets . . . lighthearted exercises in camp," asking "Could 'sestinism' be evidence of the degree to which poetry-as-play and the New York School has come to define American poetry?" 33

Indeed. Most contemporary sestinas descend, not from Bishop or Justice, but from the putatively antiacademic writings of the New York School poets, especially Ashbery and Kenneth Koch (who wrote a sestina collaboratively in the 1950 s). Kent Johnson has recently published a sestina whose end words name those poets:

It's interesting how no one has yet written a sestina about John Ashbery, Joseph Ceravolo, Barbara Guest, James Schuyler, Frank O’Hara, and Kenneth Koch.

After all, the New York poets wrote a bunch of sestinas, and Frank O'Hara,

of course, though he never wrote one himself, dropped the names of poets in his poems like crazy. James Schuyler

did too. ${ }^{34}$

Ashbery's 1956 sestina "The Painter" now shows up in many anthologies. The eponymous painter attempts to "paint the sea's portrait," fails, finds that "all indications of a subject / Began to fade," and dies by falling off a building. ${ }^{35}$ The poem invites us to see it as an allegory of antifoundationalism, of the death of the (artistic) subject, or of the replacement of topic by technique, all of which readers sometimes associate either with Ashbery or with postmodernism in the arts generally. Whatever the sense of its symbols, "The Painter" feels and sounds more like its serious 1950 s cousins than like the sestinas of our moment.

More important to the current crop is Ashbery's 1970 sestina "Farm Implements and Rutabagas in a Landscape," whose end words-"spinach," "thunder," "apartment," "country," "scratched," and "pleasant"-squirm away from attempts to fix them as weighty symbols. The poem tells a story, or a cartoonish parody of a story, about Popeye, the Sea Hag, Olive Oyl, and Wimpy, who spend a "day in the country." There they encounter a parody of Romantic dejection (if not indeed of Wordsworth's "Resolution and Independence"), seeking moral and practical lessons by contemplating a roaring storm, a pastoral setting, a mysterious spoken message, and the debility of

33. Arnaut Daniel [pseud.], comment on "Trial Run," post to Accommodatingly blog, December 28, 2006.

34. Kent Johnson, “Sestina: Avantforte," Fascicle 1 (2005), http://www.fascicle.com/ issue01/Poets/kentjohnson3.htm.

35. John Ashbery, Selected Poems (New York: Athenaeum, 1985), 21. 
old age. Olive Oyl warns, "No more shall pleasant / Rays of the sun refresh your sense of growing old, nor the scratched / Tree-trunks and mossy foliage, only immaculate darkness and thunder"; thunder, when it arrives, turns out to be a burp, and Popeye, satisfied, scratches his balls. ${ }^{36}$

If "The Painter" suggests that any project of deliberate representation will fail-no matter whether the thing to be represented is the world, the work of art, or the artist-"Landscape" suggests that a deliberately arbitrary, studiously comic, project of malrepresentation, of taking inherited properties and characters the "wrong" way, can alter the world not a jot and yet succeed as art. The long lines, sometimes rococo sentence structures, and (in several senses) cartoonish characters seem designed to render ridiculous any attempts to decode them either as allegory or as representations of characters: if Popeye and company obey any laws or rules at all, they are the formal rules of the sestina, whose end words seem to dictate their actions. And those undermotivated actions become an exuberantly campy parody or undercutting of serious lyric, in general, and of Romantic crisis odes (such as "Resolution and Independence"), in particular, which aspire (as Ashbery's poem does not) to consistent representations of psychological truths, representations that might help us solve psychological or spiritual problems that arise outside of poems. Misinterpretations of Popeye, of Romantic tropes, of erotic love, and of fate can give us a "pleasant day in the country," and poets perhaps mistake their mission if they aspire to much more.

This sort of comic outrage conducted upon both form (had there even been a more irreverent sestina?) and literary inheritance (of pastoral, for example) has become one of Ashbery's standard procedures, not only with sestinas but with lyric more generally. The same years that produced this sestina produced "Daffy Duck in Hollywood" and "Variations, Calypso, and Fugue on a Theme of Ella Wheeler Wilcox," whose "mannerism of laughter and uncertainty," as Mark Silverberg has recently put it, "leaves readers quite unsure about how to take" them. ${ }^{37}$ Such uncertainty (we might even say "failure," not in the sense of aesthetic failure but in the sense of failure to support-or even make-discursive claims) has rightly become a point of departure for Ashbery's critics. "A relatively high number of the sentences in his

36. Ibid., 105-6. Compare William Wordsworth, "Resolution and Independence," in his Selected Poems, ed. Stephen Gill (London: Penguin, 2005), 137.

37. Mark Silverberg, "Laughter and Uncertainty: John Ashbery's Low-Key Camp." Contemporary Literature 43 (2002): 285. 
poetry," Thomas Fink writes, "seem to 'ask' not to be taken seriously as the direct expression of information that matters." ${ }^{38}$ In "willfully mixing and confusing such value-laden categories as serious and humorous, high and low," Silverberg explains, "Ashbery raises questions about traditional notions of poetic value"; his readers may feel they "are observing" not claims about the world but "the performance of a clever fool who follows his own arcane and amusing rules of composition." ${ }^{39}$ And the sestina-a form based in arbitrary limits anyway, a form that never pretended to mimic spontaneous, naturalistic speech (the kind of speech that arises when we attempt to describe, without premeditation, what we see or do)-well represents that Ashberian world.

"Landscape"-not "The Painter" and certainly not Hecht or Justicemakes a good starting point for understanding the sestinas of today's youngish writers, who often share Ashbery's diffident, diminished assumptions about what poems can do. (Johnson's sestina pays explicit homage to "Landscape," requesting "Olivia Oil." $)^{40}$ Not all the poets named above could possibly call themselves the heirs of Ashbery-indeed, one point of interest in the recent spate of sestinas is the way in which it crosses boundaries of school, influence, and poetic inheritance. Technical achievement becomes for many of these sestina writers-those who pick up Ashbery's style and those who do not-neither a guarantee of inheritance nor a badge of belonging to any particular tradition nor (as in Bishop) a way of adjusting to narratively specifiable loss. Instead it is something that remains-perhaps all that remains-of the idea of value in poetry after various more ambitious, or more substantive, claims about poetry's worth have been discarded or worn away.

Ashbery's Flow Chart (1992) incorporates a double sestina, with end words taken from Algernon Charles Swinburne, another poet known for flaunted artifice. If the Flow Chart sestina is "about" anything ("aboutness" being even more problematic in that book-length poem than in most of Ashbery), it is about Ashbery's desire to continue writing, to keep on imagining poetry as communication, in the absence of any particular belief or claim he holds long enough to communicate it. The double sestina (like Flow Chart generally) touches on all sorts of temporary subjects, and yet its only permanent subject appears

38. Thomas Fink, "The Comic Thrust of Ashbery's Poetry," Twentieth Century Literature 30 (1984): 1.

39. Silverberg, "Laughter and Uncertainty," 287, 289.

40. Johnson, "Sestina: Avantforte." 
to be the search for topics that can sustain some sense that Ashbery has communicated something to someone. "In all our lives I still continue to try to make headway," Ashbery writes, "and though to her I what I do never makes much sense, I do it anyway, for thee." ${ }^{41}$ In a passage that follows the double sestina almost immediately, he calls "it"-perhaps poetry, perhaps speech-"a currency / no one had any use for." 42

Ashbery's anxiously or baroquely ironized considerations of poetry's value-along with the influence they have had-suggest that we are closer than we might think to the situation of poetry in the American 1890s, the subject of John Timberman Newcomb's book Would Poetry Disappear? "Turn-of-the-century Americans," Newcomb explains, "often despaired of believing ... that poetry could be of continued value to their modern world." 43 "Before 1910 . . the economic unviability of verse had become a truism throughout the publishing industry"; "Americans ... still committed to literary poetry" had to "acknowledge the obsolescence of its existing cultural functions and worked to reimagine its possible uses, often by adapting or parodying conventions of mass culture." ${ }^{44}$ Newcomb's fears sound familiar. Without "much sense," without instrumental utility, with only dubious relation to the people whom we imagine as hearing or reading it, why should there be contemporary poetry? Why should we care whether Ashbery-or anyone else-continues to write it?

For all his diffidence, Ashbery raises that question; so do his critics, who may even attempt to answer it. Angus Fletcher has made the sestina within Flow Chart a centerpiece in his New Theory for American Poetry, which suggests that the truly American poet pays homage to flux over fixity, to a continually unfolding environment rather than to a stable horizon. Fletcher finds value in this homage, partly because it demonstrates how Americans might reconcile respect for achievement with egalitarian open-mindedness: "Ashbery's double sestina gives the reader an idea of democratic excellence, since the chivalric and elite poetic form ... so like a great athletic tournament, is embedded in the open, diagnostic, democratic excursion" of the rest of the book's free verse. ${ }^{45}$

41. John Ashbery, Flow Chart (New York: Knopf, 1991), 191.

42. Ibid., 194.

43. John Timberman Newcomb, Would Poetry Disappear? (Columbus: Ohio State University Press, 2004), xvii.

44. Ibid., 48, xxv.

45. Angus Fletcher, A New Theory for American Poetry (Cambridge, MA: Harvard University Press, 2005), 222, 224. 
Fletcher is right to note the athletic or competitive element in the form as Ashbery uses it, and he is right to see the sestina as the core of that book, if such a book can have (in another Ashberian phrase) "a visible core." ${ }^{46}$ But he perhaps underrates the uncertainty others find in Ashbery, an uncertainty about whether words in general, and poetry in particular, can bridge the gap between one subject and another, whether words can do anything at all. An Ashbery poem is "sad because it wants to be yours and cannot." ${ }^{47}$ I take that uncertainty and that sadness as central to Ashbery's projects, whose evasions insist that, for him, they cannot be dispelled. The strong formal closure of the sestina-in Ashbery as in Fuhrman, Kocot, Clover, or Van Jordan-plays against those evasions, suggesting, alas, that whether a poem gets finished does not depend on whether its questions get answered, that merely formal closure is the only kind of closure we can have.

The zenith (or the reduction to absurdity) of the contemporary sestina may be Jim and Dave Defeat the Masked Man, a book of sestinas by James Cummins, David Lehman, and both together (and in one case by Denise Duhamel). Cummins and Lehman's preface, a slippery parody of Wordsworth's preface to Lyrical Ballads, claims the sestinas "were written chiefly with a view to ascertain the ratio of pressure to success in the execution of a maneuver be it in the competing realms of athletics or aesthetics." ${ }^{48}$ Many of these sestinas name other poets; many mock those other poets' aspirations to cultural consequence and to spiritual (not to mention sexual) power. In "Fling," for example, a flirtatious couple, "awkward, shy, trying to be funny," "couldn't get any more mileage out of Gary Snyder." "Gary Snyder" and "funny" are two of the end words. Other poems poke ribald fun at the Iowa Writers' Workshop. ${ }^{49}$

Cummins (who published in the 1980s a book of sestinas about Perry Mason) has argued that a sestina's end words "are signpostseach time you come around them you are made aware (one of their

46. John Ashbery, "Self-Portrait in a Convex Mirror," in his Selected Poems, 190.

47. John Ashbery, "Paradoxes and Oxymorons," ibid., 283.

48. Cummins and Lehman, Jim and Dave Defeat the Masked Man, 15; cf. Wordsworth's "experiment which, I hoped, might be of some use to ascertain, how far, by fitting to metrical arrangement a selection of the real language of men in a state of vivid sensation, that sort of pleasure . . may be imparted, which a Poet may rationally endeavour to impart" (William Wordsworth, "Preface" [1800], in Wordsworth and Samuel Taylor Coleridge, Lyrical Ballads, ed. R. L. Brett and A. R. Jones [London: Routledge, 1991], 241). "The real language of men" has been replaced by "the execution of a maneuver."

49. James Cummins and David Lehman, "Fling," in their Jim and Dave Defeat the Masked Man, 26; see also David Lehman, "Big Hair," ibid., 40. 
very important functions is to make you aware) of the passage of time: this word is the 'same,' but only in the sense [that] a human being is the same at different ages." ${ }^{50}$ Within Jim and Dave, a sestina called "The Thirty-nine Steps"-whose thirty-nine lines have everything to do with turning forty, and not much to do with John Buchan or with Alfred Hitchcock-takes advantage of that awareness:

These graduation ceremonies were a cross,

Usually, of the stupidly funny and the stupidly boring. The speech

Of formal gibberish, the inaccurate notion that all youths

Become men at precisely the same instant, the way it

All seemed as opaque and foolishly friendly as an adage

Or an order issued by a mother. "Act your age,"

Mine still says to me, and at twenty-eight I'm still not very

Clear as to what that means. Does it

Imply, for example, a mandatory choosing at every which cross-

Roads? ${ }^{51}$

The poem endorses, and fleshes out, Ashbery's well-known recommendation that "thinking not to grow up / Is the best kind of maturity for us." ${ }^{2}$ Maturity, here, means having to make a choice, but the sestina (as Cummins's essay suggests) replaces choice with repetition: it also turns speculation about the life course into a display of (perhaps fruitless) skill. To keep the poem going means to remain shy of its end, not to settle on one purpose and grow up: it is, in Ashbery's own words, "fence-sitting"-that is, indecision and inaction-"Raised to the level of an esthetic ideal." 53

If "The Thirty-nine Steps" defends immaturity (a state of not having decided what one wants or means), other sestinas in the collection defend (as Fuhrman had) word games, "codes, ciphers and encrypted citations / In fortune cookies." 54 Not the message but the decoding is the point: "In art the means justify the ends." ${ }^{55}$ Cummins and Lehman also mock the idea of poetry's efficacy by depicting themselves as secret agents who have daring adventures or parodies of adventures: in one poem they "Rescue Denise Duhamel from a Summer

50. James Cummins, “Calliope Music,” Antioch Review 55 (1997): 156.

51. Cummins and Lehman, Jim and Dave Defeat the Masked Man, 73-74.

52. John Ashbery, "Soonest Mended," in his Selected Poems, 88.

53. Ibid.

54. James Cummins and David Lehman, "In Turning from Home, It Was Secretariat," in their Jim and Dave Defeat the Masked Man, 100.

55. James Cummins and David Lehman, "End Note," ibid., 91. 
Writers' Conference"; in another they "Are Put On Administrative Leave." ${ }^{56}$ Such titles-along with the jokes about Iowa-illustrate the dangers in the hyperprofessionalism that Jim and Dave both exemplifies and derides. The most creative entertainers are those who want to do more than entertain, and it is not clear from this book whether Cummins and Lehman even have consistent desires or claims on the world that they want to embody in their art (a different matter from believing that art can make good on those claims, make them come true). "The poem's first purpose is to give pleasure," they write; they do not give a second purpose, adding, "The word is the result of the wish for the word." ${ }^{57}$ Cummins and Lehman's sestinas reiterate the notion that craft and entertainment are what we have now, but they lose the frustration, the balked nostalgia, for untenable modernist and Romantic projects which Clover, Fuhrman, Ashbery, and Thorburn all retain.

The current wave of sestinas both reflects diminished expectations and gives poets ways to explore them since the form can embody at once impotence and artifice, arbitrariness, inconsequence, and technique. Poets of the last decade seem drawn for those reasons first to sestinas and then to other forms whose obviously arbitrary, more or less technically challenging, constraints do not partake of rhyme or meter. Take, for example, the lipogram and the anagram, forms linked not to English tradition but to Oulipo, the Continental movement that Paul Hoover dubs "the bridge between left and right formalisms" in contemporary verse. ${ }^{58}$ These obviously constrained but nonrhyming forms permit, as the sestina does, kinds of sad play that reveal writers' sense of helplessness, their failure to find stable grounds for value in poems.

Writers of the self-identified avant-garde, such as Brian Kim Stefans, Tan Lin, and Rodrigo Toscano, have gravitated to the Oulipian heritage: CalArts in 2005 held the second of two conferences entitled "noulipo," in which such writers explored Oulipian ideas. ${ }^{59}$ Again, though, this

56. Ibid., 112, 118.

57. James Cummins and David Lehman, "The Old Constellation," ibid., 130.

58. Paul Hoover, Fables of Representation (Ann Arbor: University of Michigan Press, 2004), 5 .

59. Joseph Mosconi, "This Is Our Only World: A Report on the n/Oulipo Conference," Harlequin Knights blog, November 2, 2005, http://harlequinknights.blogspot.com/2005/ 11/this-is-our-only-world-report-on.html. 
interest extends beyond any one school. In Michael Smith's series "Anagrams of America," for example, "all of the letters of [each] source text have been used, once and only once, in the composition of the corresponding poem." ${ }^{60}$ Smith's "Plan" rearranges the letters in Benjamin Franklin's "Plan for Future Conduct." It asks whether the poet might become one of those who (like Franklin, or like "software / giants, ex-hackers") put specialized linguistic skills to civic or commercial use:

Troubleshooters, key specialists

flown in to exact purpose yet no

further ado, then flown back home again.

One of the sought-after, needed, few.

Smith concludes that no such fate awaits the makers of contemporary verse:

Bound by boundlessness, appalled

by applause, overreaching

in despair-The poet at home

in a prose nation. He weathers his vast, unforgiven country like a storm. ${ }^{61}$

Terrance Hayes's series "A Gram of \&s" uses the letters in each poem's one-word title, or a proper subset thereof, for all eleven of each poem's line endings. "Example" warns that it may not accomplish anything: "Sometimes when you peel / back the bright wrapper of Metaphor, there is nothing but a lame / blank below." 62 "Apothecary" imagines the poem as a failed or imaginary drug, or as a placebo:

Where we're told they

House the Panacea Theory.

Where they get inside the mystery ache

\& prescribe a therapy

That needs no pray-

Er. You'd like to be indestructible like the roach

So you follow the path

To the one some say will be able to hector

Your despair. Or at least take care

Of the dry path

Of skin around your heart. ${ }^{63}$

60. Michael Smith, "Anagrams of America," Mudlark 30 (2006), http://www.unf.edu/ mudlark/mudlark30/contents.html.

61. Ibid.

62. Terrance Hayes, Hip Logic (New York: Penguin, 2002), 36.

63. Ibid., 30. 
Nothing in the poem absolutely compels us to treat its healer as a version of the poet, just as nothing in Kocot's sestina required us to read her fortune-teller as a parodic vates. And yet Hayes's "one," whose "panacea" replaces religion ("needs no pray- / Er"), heals the heart, and relies upon words and ideas ("theory"), seems very much an Arnoldian figure, a literary and spiritual "physician" who might say, with Arnold's Goethe, "Thou ailest here, and here." ${ }^{4}$ In Hayes's construction, though, no such person exists-the "dry patch" persists: the miracle treatment (or poet or poem) has not arrived.

Linked to the anagram is the lipogram, a text that avoids selected letters, such as Georges Perec's La Disparition (in English, A Void), in which no words contain the letter $e .{ }^{65}$ The Canadian poet Christian Bök has written lipogrammatic prose poems, collected as Eunoia, which use and reuse only one vowel per page. Bök takes to parodic extremes the idea that poetry is, at bottom, an ingenious craft-that poems are much less like prophecies than they are like spelling bees. In the mock manifesto of "Chapter E," Bök both mulls and mocks the idea that technical innovation amounts to (or even tropes) cultural rebellion:

Enfettered, these sentences repress free speech. The text deletes selected letters. We see the revered exegete reject metred verse: the sestet, the tercet. . . . Relentless, the rebel peddles these theses, even when vexed peers deem the precepts "mere dreck." The plebes resent newer verse; nevertheless, the rebel perseveres, never deterred, never dejected, heedless, even when hecklers heckle the vehement speeches. We feel perplexed whenever we see these excerpted sentences. We sneer when we detect the clever scheme-the emergent repetend: the letter E. We jeer; we jest. ${ }^{66}$

Teasing the skeptical audience he projects, Bök describes a technique that rejects, as he puts it, both traditional forms and "genteel speech," a rebellion pertaining to nothing but form. ${ }^{67}$

Newest and most provocative among all these constrained forms is the Flarf poem or Flarf Google-sculpture, created by editing and conjoining phrases from Internet search engines, often with parodic or absurdist

64. Matthew Arnold, "Memorial Verses," in his Selected Poetry and Prose, ed. Frederick Mulhauser (New York: Holt, Rinehart, \& Winston, 1967), 9-10.

65. Georges Perec, La Disparition (Paris: Editions Denoël, 1969), and A Void, trans. Gilbert Adair (London: Harvill, 1994). The French original (but not the English translation) includes a prefatory sonnet by another Oulipian, Jacques Roubaud, also devoid of $e$ (Perec, La Disparition, 9).

66. Christian Bök, Eunoia (Toronto: Coach House, 2001), 31-32.

67. Ibid., 32. 
goals. ${ }^{68}$ Now the subject of long debates in the Internet journal Jacket and elsewhere, even of a Flarf Festival in Chelsea, such poems interest me here because, whenever they are linguistically memorable (and often when they are not), they combine a devotion to an obviously arbitrary and tightly constraining external form with a tone of self-mocking, even self-hating futility. The best of the Flarf books, The Anger Scale by Katie Degentesh, derives its lines from searches on phrases from the Minnesota Multiphasic Personality Inventory, the well-known test for mental illness; the same phrases, unaltered, produce her titles. Her poem "My Hands Have Not Become Clumsy or Awkward" begins: "Sometimes I find that my hands have become aware of each other, / or that they have become so weak that singing has become impossible. // In addition to the Truth, the pointy spikes on my new car also hurt." The same poem declares: "Oh, how I want to make someone happy. // I feel sort of mechanical / I guess I need some new dish soap." ${ }^{99}$ Degentesh's tone of hollow, bitter exhaustion, her sense that she cannot sing, surrounded by things, seems to me as genuine as the awkwardness of the diction: the idea of the Flarf poem as a balked ars poetica, as a computer-assisted outcry against impossible demands, extends throughout her disturbing book.

\section{III}

The sestina, I have been claiming, behaves for younger American poets more like the anagram, the lipogram, and even the Google-sculpture than like the sonnet and the couplet-it is a difficult form whose difficulties seem arbitrary and whose accomplishments carry little cultural weight. The sestina thus fits a poetics of diminished, regretful, comic self-skepticism, owing much to John Ashbery, in which only craft and entertainment remain as aspirations poets can actually reach.

Sestina form, I have been arguing, becomes in recent American poetry a response to conditions in which the writing and reading of poetry seems to have surprisingly few consequences beyond entertainment and the self-justifying refinement of craft. These conditions have prompted some recent critics to make complicated claims about poetic value: prompted, that is, new arguments that amount to defenses of poetry, claims for its ethical use or for its special powers that go

68. For an explanation of Flarf and an introduction to the debate around it, see Rick Snyder, "The New Pandemonium: A Brief Overview of Flarf," Jacket 31 (2006), http:// jacketmagazine.com/31/snyder-flarf.html.

69. Katie Degentesh, The Anger Scale (Cumberland, RI: Combo, 2006), 48. 
beyond an intuitive, or tautological, “art for art's sake." These defenses of poetry are sometimes defenses of artifice, insistences that poems have a paradoxical utility in uselessness or a Kantian purposefulness without purpose.

In one such defense, Charles Altieri has described Auden, Wallace Stevens, and George Oppen as "honoring the force of the imaginary while using the resources of art to separate that force from the images and social roles whose authority is usually reinforced by our selfprojections." 70 Their poetry, and that of their heirs, Altieri adds, might help literary critics to "accept the authority of those who work directly with the imaginary" and to "grant ... that imagined and imaginary actions cannot compete with discursive philosophy in articulating and justifying what best serve as our fundamental beliefs." 71 In a kind of neo-Laocöon, Altieri implies that poets should highlight these kinds of disillusioning or self-enclosing artifice since they are what poetry does best.

Fuhrman's and Kocot's sestinas, Bök's and Hayes's anagrams and lipograms, and the other poems in numerically and alphabetically constrained forms, we have seen, present themselves simultaneously as homages to artifice as artifice and (very much unlike New Formalist work from the 1980s) as diminished, humbled, discouraged continuations of an anti-naturalistic modernist project. We might argue that the best of them do just what Altieri's essay hopes poems will do. At the same time we need not concur with his formulation, which seems to readmit ethical and instrumental claims through a sort of back door: Altieri appears to say that the most ethically useful poetry is that which reminds us of how little ethical use, how unlike an ethical action, poetry now is-thus asking us to cherish poems for their ethical utility after all.

Similar arguments pervade the later criticism of Auden himself, who remarked that if poetry had an "ulterior purpose," it was "to disenchant and disintoxicate." 72 Richard Wilbur suggested that his own forms served a similar purpose. "Strict poetic forms, traditional or invented," Wilbur wrote in 1950, "limit the work of art, and . . declare its artificiality: they say, 'This is not the world, but a pattern imposed upon the world or found in it." 73 We may wonder how useful any poetics

70. Charles Altieri, “The Fate of the Imaginary in Twentieth-Century Poetry," American Literary History 17 (2005): 85.

71. Ibid., 92.

72. W. H. Auden, The Dyer's Hand (New York: Vintage, 1962), 27.

73. Richard Wilbur, "The Genie in the Bottle," in Mid-Century American Poets, ed. John Ciardi (New York: Twayne, 1950), 7. 
is by which Ashbery and Wilbur-as talented as they are-appear to pursue the same ends by the same means. We may also wonder whether an argument that leads us to celebrate disillusion, to think better of self-isolating artifice than the artificers themselves do, does not omit too much of the discontent (not to mention the comic instability) we see in these recent poems. Van Jordan and Fuhrman and Ashbery and Bök-and Stevens, although not the later Auden-regret that their poems cannot do more, that their poems are forever only poems: their formal constraints can emphasize that regret.

Recent sestinas' skeptical attitudes, their diminished sense of what poetry can do, seem far preferable to various now mostly lost illusions (that pentameters can regenerate lost social unity, for example, or that free verse might levitate the Pentagon ${ }^{74}$ ). Yet to be worth defending, a formalism that defends or even comprehends the best sestinas-and lipograms and anagrams-needs to acknowledge that poems are not only forms; they are also versions of communications, text messages, if you like, if not tropes for speech. Even Perloff has acknowledged as much, writing that the same Language writers who repudiated "voice" as a matter of principle (and hence appeared to deny their own poetry any communicative or semantic function) nevertheless imply "expressivity or subjectivity as such," a communicating person within each of their works of art, someone with something, somehow, to say. ${ }^{75}$

The same poets whose sestinas or Oulipian forms show frustration with their poems' inconsequence may also highlight a more optimistic view of poems as interpersonal communications, as verbal objects that can offer the right readers something after all. We can find that cautious optimism in the formal choices those poets make if we shift our attention from forms as such (e.g., couplets, sestinas, or lipograms) to subgenres and poetic kinds. As Alastair Fowler contended twentyfive years ago, "Most short poems of our time belong to well-defined subgenres. But these modern subgenres are so numerous that, being mostly unlabeled, they are unrecognized in the main, and hard to describe." ${ }^{76}$ Examples might include the travel poem (with its subgenres

74. For the supposed correlation between "traditional meter" and the "full life of the spirit," see Yvor Winters, In Defense of Reason: Primitivism and Decadence; A Study of American Experimental Poetry (Denver: Swallow, 1947), 150; for Allen Ginsberg's famous attempt to levitate the Pentagon, the best known of many accounts remains Norman Mailer, The Armies of the Night (New York: New American Library, 1968).

75. Marjorie Perloff, "Language Poetry and the Lyric Subject," Critical Inquiry 25 (1999): 432.

76. Alastair Fowler, Kinds of Literature (Cambridge, MA: Harvard University Press, 1982), 114. 
of poems on arrival, poems on departure, and poems of imaginary voyage); the poem that catalogs otherwise-unconnected symbols for the self, sometimes marked by anaphora on the phrase "I am"; and the epistolary poem (with its subgenres of poem as intimate letter, "heroic epistle" in the manner of Ovid, poem as fragmentary or enciphered missive, and so on). ${ }^{77}$ The last-named form, by definition, implies that it has, or can have, an imagined recipient, one who can take a particular interest in its implied author or in its subject. ${ }^{78}$ It may be no surprise, then, to find that some of the same American poets who explore their frustrations via recent sestinas present countervailing hopes in a variety of epistolary poems. Brian Blanchfield, for example, pens a flirtatiously evasive "Letter to a Silvery Mime in Yellow," telling a baroquely conceived, perhaps imaginary, lover that "our trembling hangs on so twisting a stem"; Prageeta Sharma begins her first book with a poem entitled "Dear "; Hayes takes up the conventions of the fan letter and of the letter from prisoner to parole board; and Joshua Clover writes passionately bizarre "postcards"-perhaps the least ironic of all his poems-in the voice of a character called Miranda, at once a teen runaway "whiz-kid" driving across the United States and an updated daughter of Prospero. ${ }^{79}$

Fowler's list of modern poetic kinds also includes the "satirical last will and testament," a subgenre that by definition asks what value the poem or poet can offer, what it can give, to others-and which then suggests irony in its answers. ${ }^{80}$ Terrance Hayes, whose anagrammatic poems we saw earlier, is represented in Legitimate Dangers not by any

77. For example, Elizabeth Bishop, "Arrival at Santos” (poem of arrival), in her Complete Poems, 1927-1979, 89-90; Joshua Clover, "1/16/91" (poem of arrival), in his Madonna Anno Domini (Baton Rouge: Louisiana State University Press, 1997), 4-5; John Ashbery, "The Bungalows" (poem of departure), in his Selected Poems, 114, and "The Instruction Manual" (imaginary voyage), ibid., 5; John Berryman, "I Am the Little Man Who Smokes and Smokes" (I-catalog poem), in his The Dream Songs (New York: Farrar, Straus \& Giroux, 1969), 22; Lucie Brock-Broido, The Master Letters (New York: Knopf, 1995) (neo-epistolary poems); Joe Wenderoth, Letters to Wendy's (Athens, GA: Verse, 2000) (neo-epistolary poems).

78. For Janet Altman, “Those works that we perceive as being the most 'epistolary,' as cultivating the letter form most fully, are those in which the I-you relationship shapes the language used" (Altman, Epistolarity: Approaches to a Form [Columbus: Ohio State University Press, 1982], 118). But see Anne Keniston, “'The Fluidity of Damaged Form': Apostrophe and Desire in Nineties Lyric," Contemporary Literature 42 (2001): 294-324. In Lucie Brock-Broido's poetry, for example, both letter recipient and poetry reader are "in the end, impossible to define or locate" (316).

79. Blanchfield, Not Even Then, 9; Sharma, Bliss to Fill, 1; Terrence Hayes, Wind in a Box (New York: Penguin, 2006), 12, 15, 25; Clover, Madonna Anno Domini, 28.

80. Fowler, Kinds of Literature, 114. 
of his anagrams but by (among others) a poem from his 2006 collection, Wind in a Box, one of several poems that share their title with the volume itself. That poem presents a self-defining, self-refuting, record of a poet's evasive legacy:

To the boy with no news of my bound and bountiful kin, I offer twelve loaves of bread. Governed by hunger, he wanted only not to want. What is the future

beyond a premonition? What is the past

beyond desire? To the preacher, I leave a new suit, a tie made of silk and shoes with unscuffed bottoms.

To the mirror, water; to the water, a book with no pages, the author's young face printed on the spine. ${ }^{81}$

The poet here insists that he has something-if only a trope or a sadness-to give. The subgenre of the poetic testament gives Hayes another way to embody and explore the problems of vocation and futility that we have seen in sestinas-and to foreground, as sestinas, anagrams, and lipograms do not, the idea that in every successful poem, the poet offers something to some reader, even if it is not always the same thing. Hayes's remarkably suggestive title means at once that his poem emanates from inspiration (as in Shelley's "Ode to the West Wind"), that it has nothing to say (it can go nowhere, being boxed up; it is, so to speak, "pure wind"), that the poet attempts the impossible (to put wind in a box), and that the poem as a made object can, after all, contain the voice of the poet.

This particular version of "Wind in a Box," being a poetic last will and testament, emphasizes the quality of bequeathing, of gift, that links a poet to his notional readers, as if the poem could will those readers (however pessimistically) into being, offering "nothing" to one, a "riddle" to another, "grace" to a third. ${ }^{82}$ Donne's poem "The Will" vents frustration with a chilly, unfaithful beloved who refused to accept the love he offered. ${ }^{83}$ Hayes may have in mind Donne's poem, or Ashbery's "Paradoxes and Oxymorons" ("This poem is sad because it wants to be yours and cannot"), or Langston Hughes's considerations of his own social duties (to which other poems in Hayes's volume refer). ${ }^{84}$ Rather than frustration with a beloved, Hayes's poetic

81. Dumanis and Marvin, Legitimate Dangers, 151; Hayes, Wind in a Box, 80.

82. Hayes, Wind in a Box, 80-81.

83. John Donne, Complete Poems, ed. John T. Shawcross (Garden City, NY: Doubleday, 1967), 136.

84. Terrence Hayes, “A Small Novel,” in his Wind in a Box, 71-72. 
testament presents instead his frustration with a history of poetry that offers an uplift narrative but not enough uplift, a public mission for artists that no actual artist can fulfill, a demand for poetic value of kinds never specified, and a substitute for religion that does not save: "These words want to answer your questions," Hayes concludes. "These words want to stave off your suffering, / but cannot. I leave them to you." ${ }^{85}$ The contemporary sestina, I hope I have shown, has said as much all along.

85. Hayes, "Wind in a Box," ibid., 81. 